\title{
SELF-HEALING TECHNOLOGY IN CONCRETE STRUCTURE DESIGN
}

\author{
Hollý I.*, Abrahoim I.** , Ondak A.***
}

\begin{abstract}
In EU countries and worldly, concrete is the most widely used building material in the world because of its strength and durability, among its other benefits. Concrete also has a certain amount of limitations. They mainly include crack formation over a period of lifetime. Crack formation in reinforced concrete constructions may result to loss of their durability. Ingress water and chemicals can cause premature matrix degradation and corrosion of embedded steel reinforcement in concrete. Regular maintenance and repair of concrete structures is costly and, in some cases, not at possible. One of possible solution for prevention a costly repair, reduce maintenance and increase material durability might be an inclusion of an autonomous self-healing repair mechanism in concrete design technology. This paper describes some types of bacteria, used in self-healing concrete and their effects on different conditions in concrete on the basis of its properties like strength, durability, absorption of water, insertion of chlorides and others.
\end{abstract}

Keywords: Concrete, Bacteria, Self-healting, Durability.

\section{Introduction}

Bacteria is a single cell organism. It is a prokaryotic cell that lack of a nucleus and other membrane enclosed structure. Typically, bacteria come in three basic shapes namely, sphere, rod-like and spiral. Some bacteria do not fit any of the preceding categories but rather have spindle shapes or irregular lobbed shapes. Bacteria can be found in every environment such as in the air, food, soil and water. Many bacteria benefits human and a few may cause disease to human. Bacteria play vital role in most of the environment cycle like biogeochemical cycle, water cycle, carbon cycle, nitrogen cycle and sulfur cycle. However, there are numbers of bacteria that is not fully characterized and only some of the bacteria have been grown in a laboratory for specific application (Irwan, 2013).

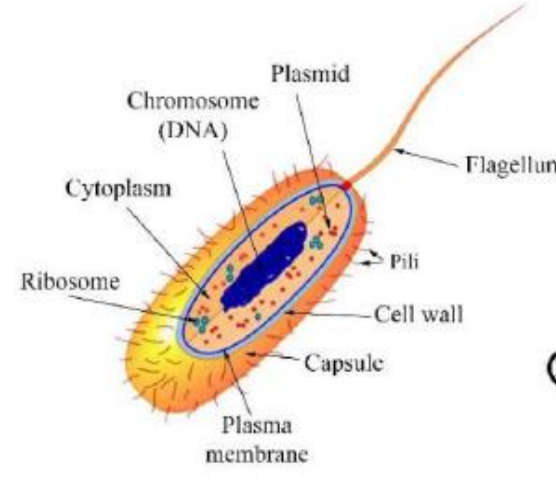

(a)

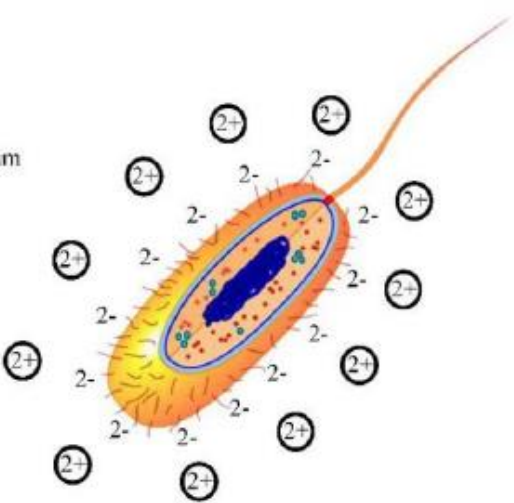

(b)

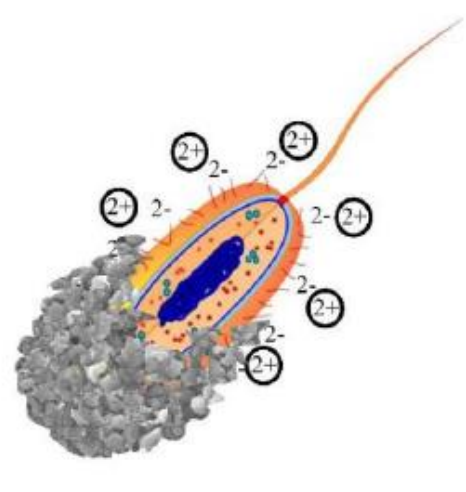

(c)

Fig. 1: (a) Bacterial structure; (b) Cell membrane (Negatively charged) surrounded by cell wall (positively charged); (c) Production of bio minerals by combination of cell wall ions and surrounding ions (Jawaid, 2018).

\footnotetext{
Ing. Ivan Hollý, PhD.: Department of Concrete Structures and Bridges, Faculty of Civil Engineering SUT in Bratislava; Radlinskeho 11; 810 05, Bratislava; SK, ivan.holly@ stuba.sk

** Ing. Iyad Abrahoim, PhD.: Department of Concrete Structures and Bridges, Faculty of Civil Engineering SUT in Bratislava; Radlinskeho 11; 810 05, Bratislava; SK, iyad.abrahoim@stuba.sk

*** Ing. Adrian Ondak.: Department of Concrete Structures and Bridges, Faculty of Civil Engineering SUT in Bratislava; Radlinskeho 11; 810 05, Bratislava; SK, xondaka@ stuba.sk
} 


\section{Role of bacteria in concrete}

The selection of the bacteria is depending on the survive capability of bacteria in the alkaline environment. Most of the microorganisms die in an environment with $\mathrm{pH}$ value of 10 or above. Strains of the bacteria genus Bacillus will be found to succeed in high alkaline environment. The bacteria survive in the high alkaline environment that formed spores comparable to the plant seeds (Luhar, 2015).

According to Eq.1, through urease activity in the presence of bacteria, one mole carbamic acid $\left(\mathrm{NH}_{2} \mathrm{COOH}\right)$ and one mole ammonia $\left(\mathrm{NH}_{3}\right)$ are produced from urea hydrolysis. As can be seen from Eq. 2, carbamic acid hydrolysis produces one mole carbonic acid $\left(\mathrm{H}_{2} \mathrm{CO}_{3}\right)$ and one mole of extra ammonium simultaneously (Seifan, 2016)

$$
\begin{gathered}
\mathrm{CO}\left(\mathrm{NH}_{2}\right)_{2}+\mathrm{H}_{2} \mathrm{O} \stackrel{\text { microorganism }}{\longrightarrow} \mathrm{NH}_{2} \mathrm{COOH}+\mathrm{NH}_{3} \\
\mathrm{NH}_{2} \mathrm{COOH}+\mathrm{H}_{2} \mathrm{O} \rightarrow \mathrm{NH}_{3}+\mathrm{H}_{2} \mathrm{CO}_{3} \\
2 \mathrm{NH}_{3}+2 \mathrm{H}_{2} \mathrm{O} \rightarrow 2 \mathrm{NH}_{4}^{+}+2 \mathrm{OH}^{-}(\mathrm{pH} \text { increase }) \\
2 \mathrm{OH}^{-}+\mathrm{H}_{2} \mathrm{CO}_{3} \rightarrow \mathrm{CO}_{3}^{2-}+\mathrm{Ca}^{2+} \\
\mathrm{Ca}^{2+}+\mathrm{Cell} \rightarrow \mathrm{Cell}-\mathrm{Ca}^{2+} \\
\mathrm{Cell}-\mathrm{Ca}^{2+}+\mathrm{CO}_{3}^{2-} \rightarrow \mathrm{Cell}-\mathrm{CaCO}_{3}
\end{gathered}
$$

To complete the last reaction (Eq. (6)), calcium ion can be provided either by internal sources that are available in the cement structure or by adding chemicals such as calcium chloride, calcium nitrate or calcium lactate externally. Precipitation of calcium carbonate crystals by Bacillus sphaericus and Bacillus subtilis are shown in Fig. 2.
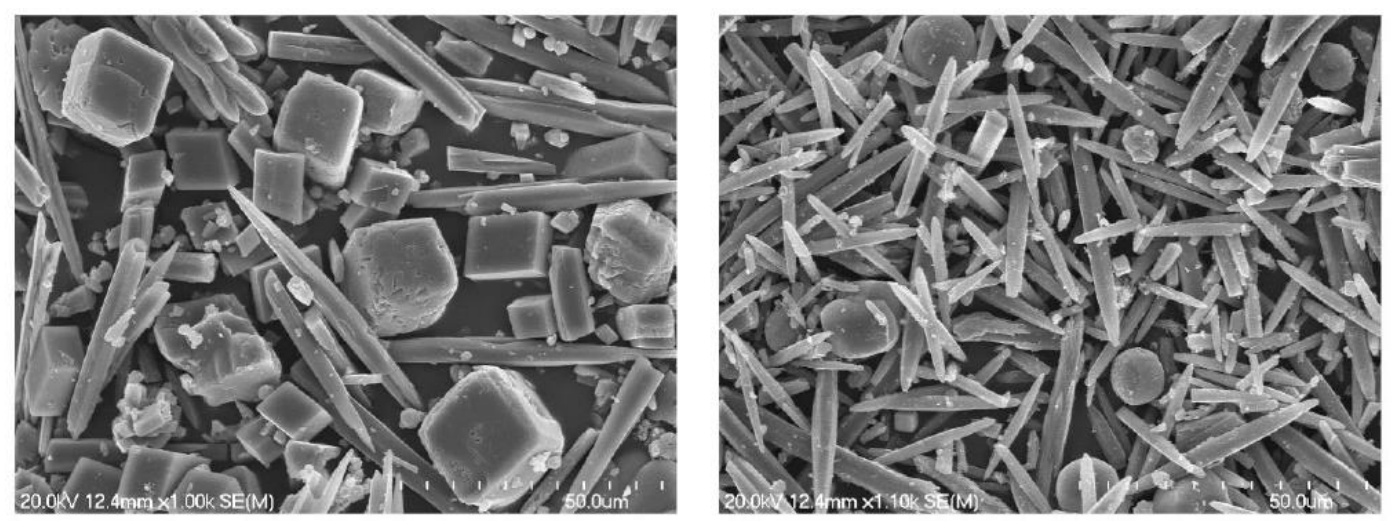

Fig. 2: (a) SEM micrographs of calcite precipitation by Bacillus sphaericus; (b) SEM micrographs of calcite precipitation by Bacillus subtilis (Seifan, 2016).

\section{Effect of bacteria on concrete properties}

\subsection{Increasing the concrete strength and the concrete durability}

Compressive strength plays important role in determining the durability of the concrete. Hence research in bio concrete is an essential field from application point of view. When bacteria species are injected into concrete and mortar, it shows significant increase on their compressive strength. Jonkers and Schlangen achieved $10 \%$ increment in the compressive strength of mortars at 28 days using a consortia of Bacillus pseudofirmus and Bacillus cohnii. (Achal, 2015) Ghosh et al. (Ghosh et al., 2005) reported an increase in the compressive strengths of $17 \%$ and $25 \%$ after 7 and 28 days, respectively in mortars due to biocementation by Shewanella species.

Jacobsen and Sellevold (Jacobsen, 1996) in their study determined the self-healing of high strength concrete after its deterioration by thaw/freeze. It was found that concrete which has lost $50 \%$ of its initial relative dynamic module during thaw/freeze and storage in water could recover completely, only with a slight variation in the degree of deterioration and concrete composition. Self-healing is considered to be the important factor providing concrete better frost durability in the field when compared to the specimens that are subjected to thaw/freeze cycles in presence of water (Jacobsen, 1996). 


\subsection{Water permeability}

As one of the fundamental parameters to characterise long term durability of concrete, resistance to water permeability is very important as it determines the penetration of aggressive substances responsible for concrete degradation. Permeability generally depends on the pore network of cementitious materials, which are quantified by variables such as porosity, size distribution, tortuosity, connectivity, specific surface and micro cracks (Phung et al., 2013). In 1993, Saint Médard Church in Thouars was repaired using calcium carbonate of microbial origin (biocalcin) that reduced five times water absorption from stones without affecting its esthetic appearance (Le Metayer et al., 1996).

\subsection{Chloride ion permeability}

Chloride ion diffusion in reinforced concrete can harm the reinforcement. Chloride-induced corrosion is one of the main mechanisms of deterioration affecting the long-term performance of building structures. (Achal, 20015). The reinforcing steel embedded in concrete is generally protected against corrosion by the high alkalinity $(\mathrm{pH}=12.5$ to 13.5$)$ of the concrete pore solution. (Bilčík, 2013). De Muynck et al. (De Muynck et al., 2008) reported that bacterial deposition of a layer of calcite on the surface of the mortar specimens resulted in a decrease of capillary water uptake and permeability towards gas, they extended their work to study other permeation properties.

\subsection{Reinforcement corrosion}

The corrosion of steel reinforcement is one of the major degradation processes of reinforced concrete structures. The main reason associated with the deterioration of reinforced concrete due to reinforcement corrosion is not the reduction in mechanical strength of the reinforcing bar itself, but rather than that the pressure exerted from the expansion of the corrosion products. This may result in damage of the structures due to expansion, cracking and eventually spalling of the concrete cover. In addition to this, the damage of construction may be caused by loss of bond between reinforcement and concrete and loss of reinforcement cross-sectional area (Bilč́́k, 2013).

In the stage of structure/member design according to code EN 1992-1-1 (2004), the corrosion of reinforcement in RC members is not considered. It is intended that the passive stage (during which the reinforcement is protected by concrete layer - concrete cover) takes a whole designed lifetime of the construction. However, as can be seen on the build structures, the protected layer on the steel/concrete interface is damaged by carbonation or chloride ingress and the reinforcement starts to corrode, this stage is so-called active stage (Strieška, 2019).

Qian et al. (Qian et al., 2009) studied increasing Bacterially induced carbonate precipitation as a novel and ecologically friendly strategy for the protection of reinforcement corrosion in cement-based materials. Theirs results showed great improvement in the surface permeability resistance of mortars due to calcite precipitated on cement specimens induced by bacterial urease enzyme, which further resisted acid attack $(\mathrm{pH}>1.5)$.

Tab. 1:Use of various types of bacteria and their results.

\begin{tabular}{|c|c|c|c|c|}
\hline S. No. & Bacteria used & Best results & $\begin{array}{c}\text { Bacterial } \\
\text { concentration }\end{array}$ & Reference \\
\hline 1 & $\begin{array}{c}\text { Bacillus } \\
\text { sphaericus CT-5 }\end{array}$ & $\begin{array}{c}\text { Compressive strength } 40 \% \text { more } \\
\text { than the control concrete }\end{array}$ & $5 \cdot 10^{7}$ cells $/ \mathrm{mm}^{3}$ & Achal, 2013 \\
\hline 2 & $\begin{array}{c}\text { Sporosarcina } \\
\text { pasteurii }\end{array}$ & $\begin{array}{c}\text { Compressive strength } 35 \% \text { more } \\
\text { than the control concrete }\end{array}$ & $10^{5}$ cells $/ \mathrm{ml}$ & Chahal, 2012 \\
\hline 3 & Bacillus cereus & $\begin{array}{c}28,56 \% \text { reduction of water } \\
\text { absorption } 90 \text { days }\end{array}$ & Saxena, 2019 \\
\hline 5 & $\begin{array}{c}\text { Bacillus } \\
\text { sphaericus }\end{array}$ & $\begin{array}{c}\text { Average } 68 \% \text { decrease of water } \\
\text { permeability }\end{array}$ & $10^{9}$ cells $/ \mathrm{ml}$ & $\begin{array}{c}\text { Wang. J. Y et } \\
\text { al., 2014 }\end{array}$ \\
\hline 5 & $\begin{array}{c}\text { Bacillus } \\
\text { sphaericus }\end{array}$ & $\begin{array}{c}40 \% \text { decrease of chloride } \\
\text { migration }\end{array}$ & $10^{7}$ cells $/ \mathrm{ml}$ & $\begin{array}{c}\text { De Muynck et } \\
\text { al., 2008 }\end{array}$ \\
\hline
\end{tabular}




\section{Conclusions}

The use of microorganisms in concrete technology is quite a new field of civil engineering. In watertight concrete structures, which reinforcement is designed to control cracks width, the quantity of this reinforcement is higher than the required static reinforcement. Adding of bacteria to concrete could reduce the reinforcement quantity in concrete designed to crack width control. Other benefits of bio concrete are higher strength and durability of concrete. Possible field of bio concrete applications in the future are water purifier tank, floor lining of water purifier in homes or industries, can be used for purifying water. Use of bio concrete technology in concrete structure design could help build more sustainable. More researches are needed to produce good quality of organic concrete in association with the microbe.

\section{Acknowledgement}

This work was supported by the Slovak Research and Development Agency under the contract No. APVV15-0658 and by the Scientific Grant Agency VEGA under the contract No. VEGA 1/0645/20.

\section{References}

Irwan, J. M. and Othman, N. (2013) An Overview of Bioconcrete for Structural Repair, in: Applied Mechanics and Materials, 389, pp. 36-39. https://doi.org/10.4028/www.scientific.net/AMM.389.36.

Jawaid, S., Ahmed, K. and Bhutto, M A. (2018) Bio concrete: an overview, International Journal of Biological Sciences, 15, 4, pp. 801-813.

Luhar, S and Gourav, S. (2015) A review paper on self-healing concrete. Journal of Civil Engineering Research, 5, 3, pp. 53-58.

Seifan, M., Samani, A. K. and Berenjian, A. (2016) Bioconcrete: next generation of self-healing concrete. Applied Microbiology and Biotechnology, 100, pp. 2591-2602.

Achal V. and Mukherjee A. (2015) A review of microbial precipitation for sustainable construction, Construction and Building Materials, 93, pp. 1224-1235.

Ghosh, P., Mandal, S., Chattopadhya, B.D. and Pal, S. (2005) Use of microorganism to improve the strength of cement mortar, Cement and Concrete Research, 35, pp. 1980-1983.

Jacobsen, S. and. Sellevold, E. J. (1996) Self-healing of high strength concrete after deterioration by freeze/thaw. Journal of Cement Concrete Research, 26, pp. 55-62.

Phung, Q.T., Maes, N., Schutter, G.D., Jacques, D. and Ye, G. (2013) Determination of water permeability of cementitious materials using a controlled constant flow method. Construction and Building Materials, 47, pp. 1488-1496.

Le Metayer et al. (1999) Applications of bacterial carbonato genesis to the protection and regeneration of limestones in buildings and historic patrimony. Sedimentary Geology, 126, pp. 25-34.

Bilčík, J. and Hollý, I. (2013) Effect of reinforcement corrosion on bond behaviour. In: Procedia Engineering: Concrete and Concrete Structures. Conference. Terchová, Slovakia, 23.-25.10.2013. 65, pp. 248-253.

De Muynck, W, Debrouwer, D, De Belie, N. and Verstraete, W. (2008) Bacterial carbonate precipitation improves the durability of cementitious materials. Cement and Concrete Research, 38, pp. 1005-1014.

Strieška, M and Koteš, P. (2019) Sensitivity of dose-response function for carbon steel under various conditions in Slovakia. In: $13^{\text {th }}$ International Scientific Conference on Sustainable, Modern and Safe Transport (TRANSCOM 2019), High Tatras, Novy Smokovec - Grand Hotel Bellevue, Slovak Republic, May 29-31, 2019.

Qian CX, Wang JY, Wang, RX, Cheng L. (2009) Corrosion protection of cement-based building materials by surface deposition of $\mathrm{CaCO}_{3}$ by Bacillus pasteurii. Materials Science and Engineering: C, 29, pp. 1273-1280.

Chahal, N., Siddique R. and Rajor A. (2012) Influence of bacteria on the compressive strength, water absorption and rapid chloride permeability of concrete incorporating silica fume. Construction and Building Materials, 37, pp. 645-651.

Saxena, S. and Tembhurkar, A. R. (2019) Developing biotechnological technique for reuse of wastewater and steel slag in bio-concrete. Journal of Cleaner Production, 229 pp. 193-202. 